\title{
Selection of Ideal Contraceptive Tool Using Hybrid Entropy-Topsis Method
}

\author{
Endang Wahyu Handamari¹, Kwardiniya Andawaningtyas² ${ }^{2}$, Corina Karim³ \\ 1,2,3 Department of Mathematics, Universitas Brawijaya
}

Email: ewahyu-math@ub.ac.id,dina_math@ub.ac.id,co_mathub@ub.ac.id

\begin{abstract}
The Hybrid Entropy-TOPSIS method is a combination of two methods, Entropy and TOPSIS. The combination of the two methods is used in the decision-making model to improve the quality of a decision. In this research, the Hybrid Entropy-TOPSIS method was applied to determine the ideal contraceptive tool based on the acceptor criteria. Entropy is a method of weighted criteria, while TOPSIS is a method of decision making through the alternative ranking process based on weighted criteria. The criteria are factors which influence to Keluarga Berencana acceptors for selecting contraceptives. The used criteria in this research were the age, blood pressure, menstrual cycle, the use of contraceptives, and the cost. While the Alternative is contraceptive tool itself. The selected alternatives here were Pill, Injection, Condoms, Implant, IUD and MOP / MOW. Based on the results of the questionnaire data and the simulation, it was obtained that pill and implants has the highest ranking and they indicated that pill and implants as an alternative selection of the ideal contraceptives.
\end{abstract}

Keywords: Contraceptive tool, Entropy, TOPSIS

\section{INTRODUCTION}

The increasing number of population is the problem for developing country like Indonesia. The population of Indonesia in 2010 as many as 237.6 million people. According to Badan Pusat Statistik [1], the population growth tend to increase, so if it is not controlled, it is predicted that in 2035 the population of Indonesia is about 305.6 million people. The increasing number of population in Indonesian is the impact of the increasing number of birth. Thus, we need to a commitment from the government and society to suppress the birth rate.

Keluarga Berencana is one of methods to suppress the population growth rates by planning the sum and the distance between the children. Some of which are family planning and the contraceptive selection. Keluarga Berencana is one of the basic health services and the most important for women. Keluarga Berencana acceptors has to determine the appropriate contraceptive tool, which is safe to use, but it is not easy. Before Keluarga Berencana acceptor chooses the contraceptive tool, the acceptor has a right to get the information about contraceptive tool. All of contraceptive methods have side effects that must be known by the user. There are various contraceptive tools, so women who use contraceptives have to make their own choice and considered appropriate. The research on the classification of the contraceptive selection of an opportunity-based using the Naive Bayes Classifier method has been done by Sobri Abusini [2], which was implemented in the form of an application program.

On the other hand, Endang Wahyu [3] use Backpropagation Neural Network algorithm to classify the effectiveness of contraceptive. In her study, Keluarga berencana acceptors will be helpful to determine the effective contraceptive tool based on their criteria, such as age, menstrual cycle, and blood pressure. Further research on Keluarga Berecana acceptors is to examine the patterns of changes in effective use of contraceptive based on the primary data of them. That research has been done by Endang Wahyu [4]. Acceptors who become the object of that research was acceptors who make a change to the use of contraceptives more than one. The method for searching the pattern is the $k$-Nearest Neighbors (kNN) algorithm to determine the shortest 
distance from several determinant factors of contraceptive and Generalized Sequential Pattern algorithm which is one of the algorithms in data mining.

Different from the previous research, in this research, the used decision-making method is based on Multi Attribute Decision Making Method (MADM). Technique for Order of Preference by Similarity to Ideal Solution (TOPSIS) which is one of the multicriteria decision-making methods where it was introduced in 1981. The TOPSIS method is one of the effective methods for MADM with qualitative and quantitative features. First, we find the Entropy by using the weighted criteria of the TOPSIS method. There are some articles that are related to the hybrid Entropy - TOPSIS, that is, Evaluation model and empirical study of human all-round development based on entropy weight and TOPSIS written by Li Gang et al. [5]. In 2014, Yancang Li et al. has writen an article entitled Comprehensive Assessment on Sustainable Development of Highway Transportation Capacity Based on Entropy Weight and TOPSIS [6]. In this research we will use hybrid from two methods, Entropy-TOPSIS, to select the ideal type of contraceptive.

\section{METHODS}

\section{The source of data}

This research was conducted at the hospital of Malang Muhammadiyah University and family planning clinic in Dau District, Malang Regency and also the respondents were the tocologists and Keluarga Berencana officer in that location.

\section{Methodology and Data Analysis}

The variables were the questionnaire data in the form of information about the detemined criteria and the weighted criteria to be achieved against the alternative. The used criteria and alternatives in this research was variable criteria, including, the age, blood pressure (systole and diastole), menstrual cycle, the cost, the experience of contraceptive methods used by the acceptor. For alternatives, it was including pills, injections, condoms, implants, IUD, and MOP / MOW. The research model to make a decission is a MADM by combining the weighted on Entropy and the ranking on TOPSIS to select the ideal contraceptive.

After obtaining the necessary informations and weighted, it were processed using the Entropy-TOPSIS method. This method was used to determine decision preferences on the data that has different units, qualitative and quantitative in each criteria. The TOPSIS was used to evaluate the obtained alternative weighted in the Entropy mehod. The steps are the following:

1. Identifications of the problem and formulations of the problem. Determining the criteria variable, which is the contraceptive selection factor, and alternative, which is the used contraceptive tool.

2. Conducting literature studies to find relevant theory references with the formulation of the problem.

3. Conducting surveys, interviews and questionnaires distribution related to the criteria and alternatives (questionnaire draft attached). The purposive sampling was used as a sampling technique. The number of Keluarga Berencana officers as respondents was determined by the highest and lowest percentage of keluarga berencana acceptors in the subdistrict.

4. Data processing of questionnaire result from criteria to alternative was using Entropy method. The output of the process is the final weighted criteria (final entropy).

5. The final weighted criteria were used as the TOPSIS method input. The output of the TOPSIS method was alternative ranking (the used contraceptive) which is the ideal decision solution. 


\section{RESULTS AND DISCUSSION}

\section{Acceptor data retrieval}

Based on the results to a number of respondents in Malang, the respondents were the General Hospital Malang Muhammadiyah University and the tocologist clinics in Dau District, Malang Regency with a total of 17 respondents. The result of questionnaire is combination of six alternatives and six criteria which are shown in Table 1 below:

Table 1. Alternative data to criteria

\begin{tabular}{|c|c|c|c|c|c|c|}
\hline & Age & $\begin{array}{c}\text { Diastole } \\
\text { Pressur } \\
\text { e } \\
\end{array}$ & $\begin{array}{c}\text { Sistole } \\
\text { Pressu } \\
\text { re }\end{array}$ & $\begin{array}{l}\text { Co } \\
\text { st }\end{array}$ & $\begin{array}{l}\text { Menstrual } \\
\text { cycle }\end{array}$ & $\begin{array}{c}\text { Experience of } \\
\text { contraceptive } \\
\text { tool }\end{array}$ \\
\hline Pill & $26-30$ & $90-99$ & $\begin{array}{c}100- \\
109\end{array}$ & Low & Normal & Fair \\
\hline Injections & $31-35$ & $\begin{array}{c}100- \\
109\end{array}$ & $\begin{array}{c}100- \\
109\end{array}$ & Fair & Normal & Fair \\
\hline Condomss & $31-35$ & $\begin{array}{c}100- \\
109\end{array}$ & $\begin{array}{c}100- \\
109\end{array}$ & Fair & Normal & Fair \\
\hline Implant & $26-30$ & $90-99$ & $\begin{array}{l}120- \\
129\end{array}$ & High & Normal & Good \\
\hline IUD & $31-35$ & $\begin{array}{c}100- \\
109\end{array}$ & $\begin{array}{c}140- \\
149\end{array}$ & High & Normal & Fair \\
\hline Mow & $41-45$ & $\begin{array}{c}100- \\
109\end{array}$ & $\begin{array}{c}140- \\
149\end{array}$ & High & Less normal & Good \\
\hline
\end{tabular}

Conversion table to get the value of each alternative criterion are shown as follow:

Table 2. Convertion in each criterion Criterion

\begin{tabular}{ccccccc}
\hline $\begin{array}{c}\text { Conversi } \\
\text { on }\end{array}$ & Age & $\begin{array}{c}\text { Diastole } \\
\text { Pressure }\end{array}$ & $\begin{array}{c}\text { Sistole } \\
\text { Pressure }\end{array}$ & Cost & $\begin{array}{c}\text { Menstrual } \\
\text { cycle }\end{array}$ & $\begin{array}{c}\text { Experience of } \\
\text { contraceptive tool }\end{array}$ \\
\hline $\mathbf{5}$ & $26-30$ & $\begin{array}{c}100- \\
109\end{array}$ & $100-109$ & $\begin{array}{c}\text { Very } \\
\text { low }\end{array}$ & Normal & Very good \\
\hline $\mathbf{4}$ & $31-35$ & $90-99$ & $110-119$ & Low & $\begin{array}{c}\text { Quite } \\
\text { normal }\end{array}$ & Good \\
\hline $\mathbf{3}$ & $36-40$ & $80-89$ & $120-129$ & Fair & Less normal & Fair \\
\hline $\mathbf{2}$ & $41-45$ & $70-79$ & $130-139$ & High & Abnormal & Bad \\
\hline $\mathbf{1}$ & $>45$ & $<70$ & $>139$ & $\begin{array}{c}\text { Very } \\
\text { high }\end{array}$ & $\begin{array}{c}\text { Very } \\
\text { abnormal }\end{array}$ & Very bad \\
& & & & &
\end{tabular}

The Entropy method

According to Wen-Yon-Zhou [7], the Entropy method is used to determine a weighted on a criterion with variations of each criterion where the highest weighted is in the highest value of variation.

Calculation of the final weighted Entropy

Let $\bar{\lambda}=\left(\begin{array}{llllll}0.025 & 0.0083 & 0.775 & 0.1333 & 0.0334 & 0.025\end{array}\right)$.

Conversion for each desired criteria by Keluarga Berencana Worker (tocologist) adjusted to the conditions of the Keluarga Berencana acceptor, it will get the final weighted Entropy. 
$W=\lambda^{*}=\left(w_{1} ; w_{2} ; w_{3} ; w_{4} ; w_{5} ; w_{6}\right)$

As a simulation if the decision maker uses the following weighting.

Table 3. Weighted simulation

\begin{tabular}{|c|c|c|}
\hline Criterion & $\begin{array}{l}\text { Acceptor } \\
\text { data }\end{array}$ & $\begin{array}{l}\text { Value of } \\
\text { conversions }\end{array}$ \\
\hline Age & $36-40$ & 3 \\
\hline Diastole Pressure & $80-89$ & 3 \\
\hline Sistole Pressure & $130-139$ & 2 \\
\hline Cost & Low & 4 \\
\hline Menstrual cycle & Less normal & 3 \\
\hline $\begin{array}{l}\text { Experience of } \\
\text { contraceptive tool }\end{array}$ & Bad & 2 \\
\hline
\end{tabular}

The weighted value for the final entropy is the following

$$
\lambda^{*}{ }_{j}=\frac{\lambda_{j} w_{j}}{\sum_{j=1}^{6} \lambda_{j} w_{j}} \quad j=1,2,3,4,5,6
$$

and the valued of $W=\lambda^{*}=(3 ; 3 ; 2 ; 4 ; 3 ; 2)$ get the final weighted Entropy, i.e:

$$
\lambda^{*}=\left(\begin{array}{llllll}
0,032147 & 0,010673 & 0,664381 & 0,228547 & 0,042949 & 0,021432
\end{array}\right)
$$

\section{Hybrid Method Entropy-TOPSIS}

The TOPSIS is one of a method that can help the optimally of decision-making process to solve the decision problem in a practical way. According to Smaradance and Ali [8], the TOPSIS is one of the multicriteria decision-making methods which is introduced by Yoon and Hwang in 1981. The TOPSIS consider the distance to the positive ideal solution and the distance to the negative ideal solution simultaneously. According to Sandeep et al [9], the TOPSIS is a method used to deal with the alternative ranking issues from the best to the worse. The TOPSIS is a method that used to solve an alternative rank from the best to the worst. Here, we use TOPSIS method for alternate ranking of contraceptives using the final weighted Entropy $\left(\lambda^{*}\right)$. The TOPSIS procedures are as follows.

1. Build a decision matrix.

Here is the $\mathrm{X}$ decision matrix refers to the $m$ alternative and will be evaluated based on $n$ criteria

$$
X=\left[\begin{array}{llllll}
5 & 4 & 5 & 4 & 5 & 3 \\
4 & 5 & 5 & 3 & 5 & 3 \\
4 & 5 & 5 & 3 & 5 & 3 \\
5 & 4 & 3 & 2 & 5 & 4 \\
4 & 5 & 1 & 2 & 5 & 3 \\
2 & 5 & 1 & 2 & 3 & 4
\end{array}\right]
$$

2. Make a normalized decision matrix.

Each element in the $\mathrm{X}$ matrix is normalized to obtain the normalized $\mathrm{R}$ matrix. Using the equation (2.10), it was obtained the normalized decision matrix from the $\mathrm{R}$ work rating matrix as follows 
Table 4. The Result of normalisastion (R)

\begin{tabular}{llllll}
\hline $\mathbf{0 , 4 9 5 0 7 4}$ & $\mathbf{0 , 3 7 1 3 9 1}$ & $\mathbf{0 , 5 3 9 1 6 4}$ & $\mathbf{0 , 5 8 9 7 6 8}$ & $\mathbf{0 , 4 3 1 9 3 4}$ & $\mathbf{0 , 3 6 3 8 0 3 4}$ \\
\hline $\mathbf{0 , 3 9 6 0 5 9}$ & 0,464238 & 0,539164 & 0,442326 & 0,431934 & 0,3638034 \\
\hline $\mathbf{0 , 3 9 6 0 5 9}$ & 0,464238 & 0,539164 & 0,442326 & 0,431934 & 0,3638034 \\
\hline $\mathbf{0 , 4 9 5 0 7 4}$ & 0,371391 & 0,323498 & 0,294884 & 0,431934 & 0,4850713 \\
\hline $\mathbf{0 , 3 9 6 0 5 9}$ & 0,464238 & 0,107833 & 0,294884 & 0,431934 & 0,3638034 \\
\hline $\mathbf{0 , 1 9 8 0 3}$ & 0,464238 & 0,107833 & 0,294884 & 0,259161 & 0,4850713 \\
\hline
\end{tabular}

3. The weighted on a normalized matrix using equations $v_{i j}=w_{j} r_{i j}$,

4. Determine the matrix of positive ideal solutions, negatives ideal solutions, separation and close to relative to the positive ideal solutions.

5. In this research, the advantages of criteria are the age, sistole pressure, diastolic pressure, menstrual cycle, and contraceptive experience. Meanwhile, the cost criterion is the cost incurred in accordance with the contraceptive used. The positive ideal solution matrix element, the negative ideal solution matrix element, and the separation were obtained based to Table 5 below. In the TOPSIS method, the optimal alternative has the nearest positive ideal solution and the furthest negative ideal solution. After an alternative distance was obtained, then the positive and negative ideal solution were calculated on the close to relative of each alternative to the two solutions, so it was obtained as follows.

Table 5. The positive ideal solution, the negative ideal solution, the separation and the close to relative to $v_{i}^{+}$

\begin{tabular}{llllll}
\hline$i$ & $v_{i}{ }^{+}$ & $v_{i}{ }^{-}$ & $S_{i}{ }^{+}$ & $S_{i}{ }^{-}$ & $C_{i}{ }^{+}$ \\
\hline $\mathbf{1}$ & 0.015915 & 0.006366 & 0 & 0.09613 & 1 \\
\hline $\mathbf{2}$ & 0.005284 & 0.002114 & 0.004873 & 0.04673 & 0.905559 \\
\hline $\mathbf{3}$ & 0.328918 & 0.263134 & 0.004873 & 0.04673 & 0.905559 \\
\hline $\mathbf{5}$ & 0.045259 & 0.113148 & 0 & 0.09613 & 1 \\
\hline $\mathbf{6}$ & 0.021263 & 0.008505 & 0.004873 & 0.04673 & 0.905559 \\
\hline
\end{tabular}

6. Sorting or ranking the alternatives.

The alternative was sorted from the largest to the smallest $C_{i}^{+}$value. The alternative with the largest $C_{i}{ }^{+}$value is the best alternative. The alternative ranking results based on the simulation are shown as follows.

Table 6. The ranking of Entropy-TOPSIS method

\begin{tabular}{ccl}
\hline Ranking & \multicolumn{2}{c}{ Entropy-TOPSIS } \\
\cline { 2 - 3 } & Preference ${C_{i}{ }^{+} \text {value }}$ & \multicolumn{1}{c}{ Alternative } \\
\hline $\mathbf{1 .}$ & 1 & Pill and implants \\
\hline $\mathbf{2 .}$ & 0,905559 & Injections, condoms, and IUD \\
\hline $\mathbf{3 .}$ & 0,749978 & MOW \\
\hline
\end{tabular}

The analysis of the calculation results using TOPSIS method of 6 criteria and 6 alternatives was obtained that pill and implant has the highest preference value of 1 . Meanwhile, injections, condoms, and IUD were in the second ranked which has a preference value of 0.905559. Furthermore, MOW was in the last ranked which has a preference value of 0.749978 . 


\section{CONCLUSIONS}

1. Based on the results of questionnaire data processing, it was obtained work rating matrix. Furthermore, by using Entropy method, it was obtained the eight Entropy vector,

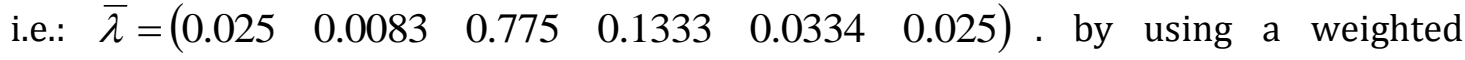
simulation $W=\lambda^{*}=(3 ; 3 ; 2 ; 4 ; 3 ; 2)$, it was obtained the final weighted entropy value, that is

$$
\lambda^{*}=\left(\begin{array}{llllll}
0,032147 & 0,010673 & 0,664381 & 0,228547 & 0,042949 & 0,021432
\end{array}\right) .
$$

2. The final determintaion entropy value was used to rank alternatives using the hybrid Entropy-TOPSIS method. The ranking results indicate the pills and implants ae the alternative selection of the ideal contraceptives.

\section{REFERENCES}

[1] Badan Pusat Statistik. Proyeksi Penduduk Indonesia. https://www.bappenas.go.id/files/.../Proyeksi Penduduk Indonesia 2010-2035.pdf. Retrieved on August 10th, 2017

[2] Abusini, S. 2013. Klasifikasi Pemakaian Alat Kontrasepsi Yang Potensional Dengan Metode Naïve Bayes Classifier. Research Report BOPTN.

[3] Wahyu, E. 2014. Klasifikasi Alat Kontrasepsi Menggunakan Metode backpropagation. Research Report DPP/SPP.

[4] Wahyu, E. 2016. Eksplorasi Pola Pemakaian Alat Kontrasepsi yang Efektif. Research Report DPP/SPP.

[5] Gang L.,Tai C.G., Qiu C.Y. 2011. Evaluation model and empirical study of human all-round development based on entropy weight and TOPSIS. Journal of System Engineering 03.

[6] Li Y., Zhao L. Suo J. 2014. Comprehensive Assessment on Sustainable Development of Highway Transportation Capacity Based on Entropy Weight and TOPSIS. Journal sustainability 6(7)

[7] Wen-Yon-Zhou. 2013. Multiple Criteria Decision Analysis State of the Art Surveys. Amerika: Springer Science. Retrieved on April 12 2017.

[8] Smaradanche, F dan Ali, M. 2013. Neutrosophic Sets and Systems. Vol.1. Mexico:University of Mexico. Diakses pada 12 April 2017.

[9] Sandeep, P.C Tewari, Prakash, U., dan Khanduja, K. 2015. Ranking of Sintered Material for High Loaded Automobile Application by Applying Entropy-TOPSIS Method. Elsevier. India. 